Volume 2

Number 2 Popular Culture and Markets in

Turkey

2017

\title{
Jan-Werner Müller, What Is Populism? (2016)
}

Özgür Gökmen

Cumhuriyet Akademi

Follow this and additional works at: https://digitalcommons.uri.edu/mgdr

Part of the Economics Commons, Political Science Commons, and the Sociology Commons

\section{Recommended Citation}

Gökmen, Özgür (2017) "Jan-Werner Müller, What Is Populism? (2016)," Markets, Globalization \& Development Review. Vol. 2: No. 2, Article 7.

DOI: 10.23860/MGDR-2017-02-02-07

Available at: https://digitalcommons.uri.edu/mgdr/vol2/iss2/7

This Book Review is brought to you for free and open access by DigitalCommons@URI. It has been accepted for inclusion in Markets, Globalization \& Development Review by an authorized editor of DigitalCommons@URI. For more information, please contact digitalcommons-group@uri.edu. 
Jan-Werner Müller, What Is Populism? (2016)

\section{Markets, Globalization \& Development Review}
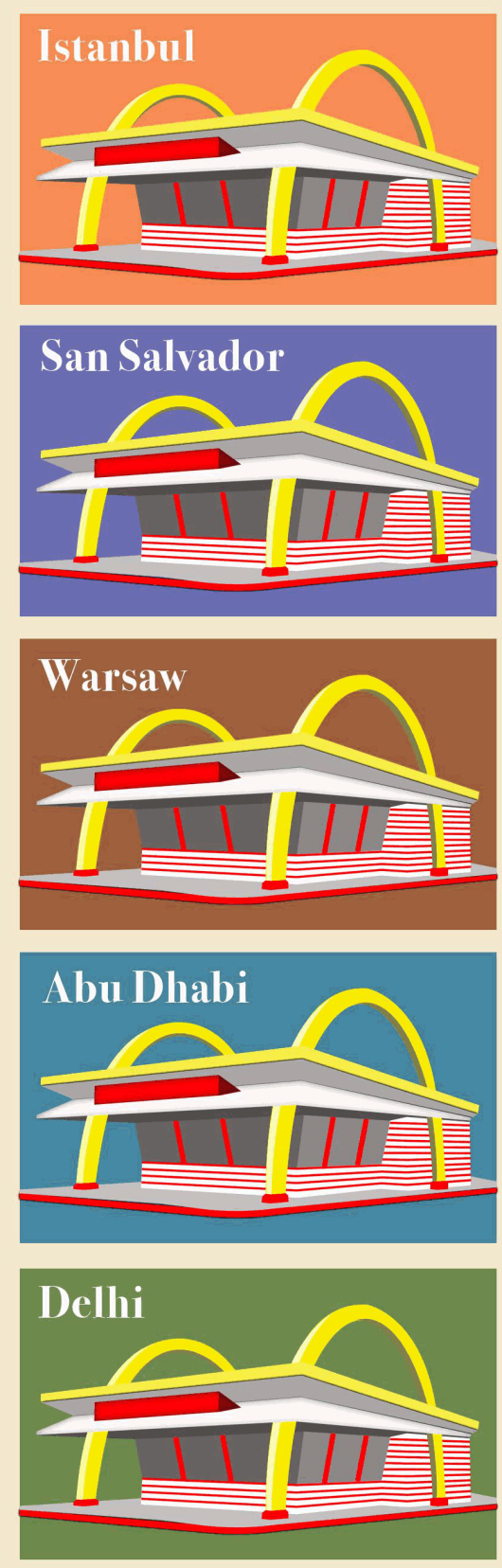
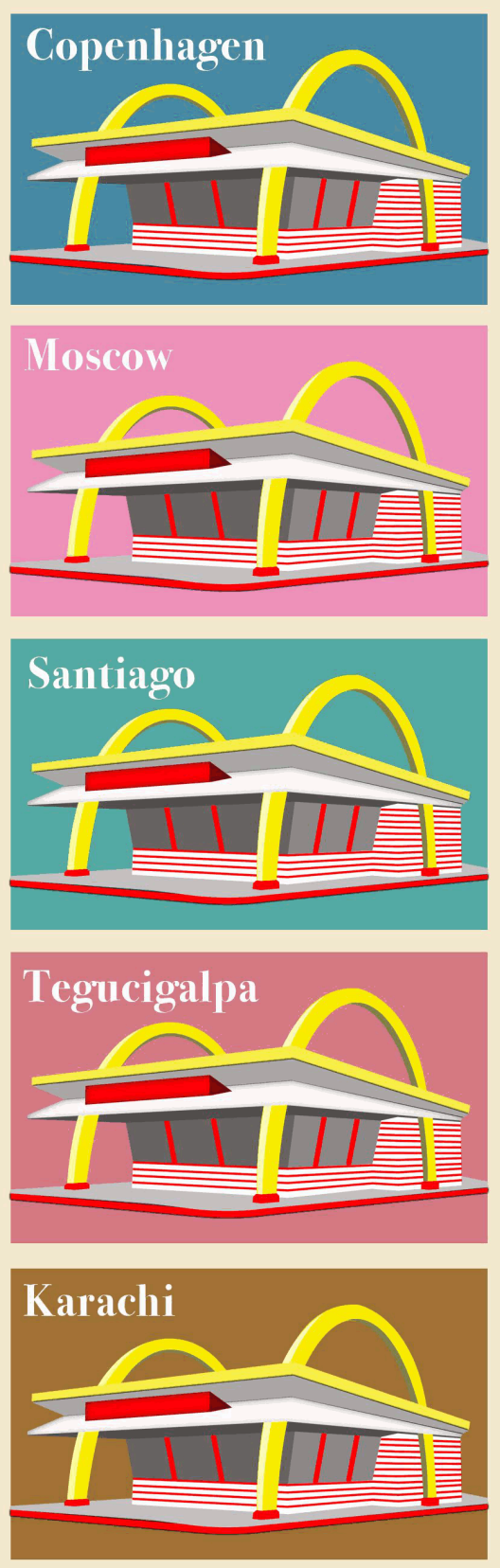
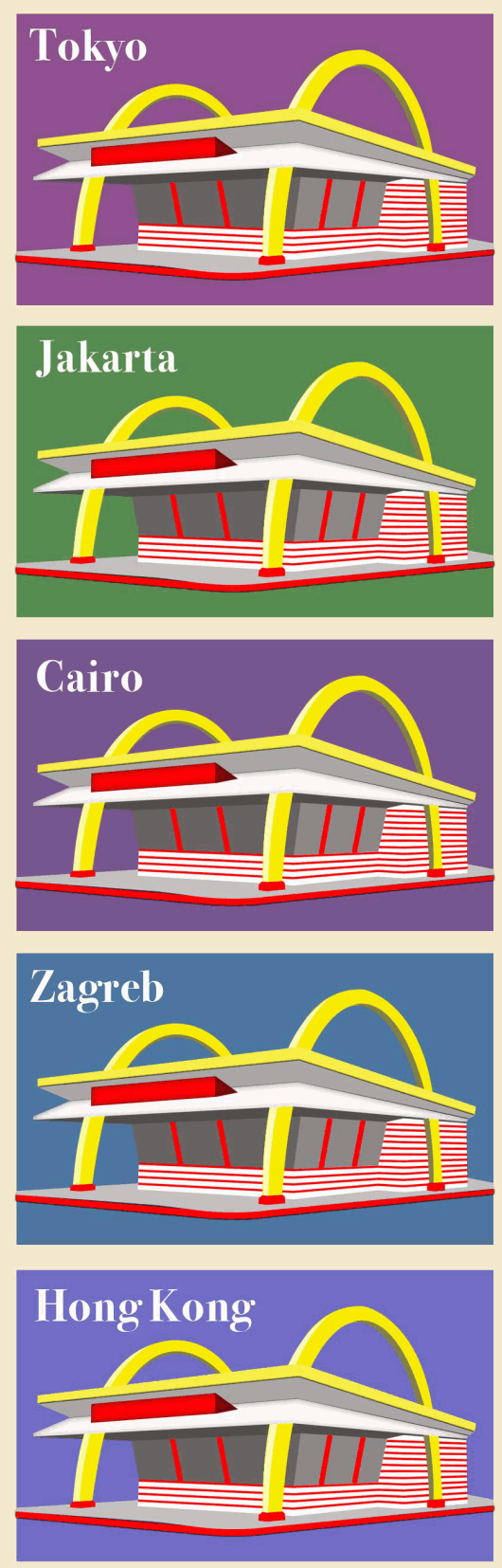

This book review is available in Markets, Globalization \& Development Review: https://digitalcommons.uri.edu/mgdr/ vol2/iss $2 / 7$ 


\section{Book Review}

\section{Jan-Werner Müller, What Is Populism? (2016)}

Populism has not always borne a pejorative connotation. But those days are long gone with political figures like Jörg Haider, Geert Wilders, Recep Tayyip Erdoğan, Viktor Orbán, and Donald Trump starting to dominate the public sphere. Nowadays, the talk of populism, "one of the main political buzzwords of the 21st century" (Mudde and Kaltwasser 2017, p. 1), as a problematic (even evil) political stance has almost become omnipresent. From conventional media outlets to every flavor of social media, one cannot stand a fair chance of not being exposed to the "notorious" concept at least a couple of times a day.

William Gibson recently tweeted that "populism, a nightmare state of democracy, can result in electing someone very foolish, or perhaps criminal, or even, perhaps, both." And for those who are unfamiliar with the name, Gibson is not a political scientist or a sociologist. He is not even a political commentator, but a well-established American-Canadian speculative fiction writer best known as the author of the cult science fiction novel Neuromancer, and the inspiration behind the Matrix films. Nevertheless, his uncomplicated and smart definition should be underlined: populism as "a nightmare state of democracy." For although a nightmare belongs to the subconscious, it is still an offspring of the mind. So is populism's relation to representative politics. There is no populism outside of the realm of representative systems. As Jan-Werner Müller (2016a, loc. 98) puts it, "the danger comes from within the democratic world." Populism is an "internal periphery of democratic politics;" populism as politics is performed on the "edge of liberalism" (Arditi 2005, 2006).

It is almost obvious that Gibson was basically referring to the rise of Trump. Populism, however, has not entered common parlance overnight. Sociopolitical developments witnessed in continental Europe during the last three decades have already proved that populism had been on the rise. In one of the recent issues, the headline that the English edition of $L e$ Monde diplomatique decided on, to announce Perry Anderson's (2017) analysis on the cover, says a lot: We are living in the age of "the populist revolutions." This state of affairs revived the academia's interest in the phenomenon once again. Not only popular, but also academic publications on the subject have increased significantly especially since the early 2000s.

2017 marks the fiftieth year of the famous conference on populism at the London School of Economics that convened to shed light on and 
develop a definition of the much-contested concept. Although that conference produced a comprehensive edition (Ionescu and Gellner 1969), which is regarded as "the definite collection on populism" (Taggart 2000), no single one theory came out of that attempt. Let alone a theory, Ghița lonescu and Ernst Gellner (1969) did not even come to a shared decision about a definition of populism.

An overview of the literature on populism can easily prove that there was no common consent on the meaning populism in the 1960s. Attempts at developing a theory (e.g., Laclau 1977) remained incomplete in the 1970s. In this way, it has become "a cliché to start writing on populism by lamenting the lack of clarity about the concept and casting doubts about its usefulness for political analysis" (Panizza 2005, p. 1). For a very long time, everyone has been talking about populism but the definitions varied remarkably, and almost all contributions started with a concession that no one knows what populism exactly is.

In his recent book, What is Populism?, Jan-Werner Müller does not substantially constitute an exception in regard to the lack of theory. Müller (2016a, loc. 38) reinforces the widely held view by mentioning "we simply do not have anything like a theory of populism" although he - as a scholar and a Professor of Politics at Princeton University - has contributed to the search for a theory. He states in the Acknowledgements of the book that one of his previous publications, which the book draws on, bears the title "Towards a Political Theory of Populism" (Müller 2016a, loc. 1858). Instead, in this short book, Müller (20016a, loc. 49) claims to provide the reader with tools to "recognize and deal with populism." Would recognizing the symptoms of a political disposition really help without a theory of the "malady" in the current age?

Before responding to this question, a point of progress should be noted. In contrast to the earlier mentioned confusion regarding the meaning of populism, the concept is not very much contested anymore. Recently, some experienced scholars in the study of populism - such as Paul Taggart (2000; 2002), Yves Mény and Yves Surel (2000), Cas Mudde (2004), Cas Mudde and Cristóbal Rovira Kaltwasser (2017) provide very similar definitions and seem to agree on the core of populism. To give a gist, populism is

an ideology that considers society to be ultimately separated into two homogeneous and antagonistic groups, 'the pure people' versus 'the corrupt elite', and which argues that politics should be an expression of the volonté générale (general will) of the people. Populism, so defined, has two opposites: elitism and pluralism. Mudde (2004, p. 543) 
Accordingly, Francisco Panizza (2005, p. 1) is nearly right in his claim that although "there is no scholarly agreement on the meaning of populism, it is possible to identify an analytical core around which there is a significant degree of academic consensus." This "theoretically elegant" core, which "provides the basis for rich empirical analysis," is presented with three elements: "a mode of identification, a process of naming and a dimension of politics". Thus, populism can be understood along the lines of these three questions: "Who are the people? Who speaks for the people? How does populist identification occur?" Müller's work falls within this analytical core.

As a rule of thumb, simplistic conceptualizations that attribute a derogatory lineament to populism should be abandoned completely for a clear analysis. There is more to populism than simply being opportunistic attempts of political leaders to win votes by embracing stances that are deemed politically incorrect. Müller escapes this trap successfully. He "rejects the paternalistic liberal attitude that effectively prescribes therapy for citizens "whose fears and anger have to be taken seriously"' (Müller 2016a, loc. 80), and argues against populism being "connected, primarily by liberal commentators, with irresponsible policies or various forms of political pandering" (Müller 2016a, loc. 167).

The current intellectual state of "reached agreement" shows us that two characteristics are central to populism: the populist leader's association with the people and a reference to the other, often the elite, against which the people are positioned. Populism as an ideology conceives of society as separated into two antagonistic groups: "the people" and "the other." Pure origins of democracy are grounded in the general will of the people. And accordingly, the people should reign supreme since they are the cultural and socioeconomic foundation of democracies. This appeal to the people is problematic, however, since there is an inherent ambiguity in the nature and function of the concept of "people" in Western politics.

The concept of the people itself bears a polar meaning. The Slavic word "narod," which stands both for "the people" and "the nation" aside, the concept of people in modern European languages names the constitutive political subject as well as the class that is excluded from politics. It always also indicates the underdog - the poor, the underprivileged, and the excluded. The Italian, French and Spanish words for "the people" all derive from the late Latin term populus, and they designate - both in common parlance and in the political lexicon - the whole of citizenry as a unitary body politic as well as those who belong to inferior classes. The English term, in a similar way, retains the meaning of 
ordinary people as opposed to the rich and the aristocracy. Thus, there seems to be a dialectical oscillation between two opposite poles: on the one hand, there are the people as a whole and as an integral body politic; and on the other, the people as a subset and as fragmentary multiplicity of needy and excluded bodies.

What populism really aspires is not to bridge over that divide, but rather to define a subset of the whole population as the owner of the general will. In any instance of populism, the people are an "imagined community." They come on the scene as a mythical and constructed subset of the whole population.

The author of this book is quite aware of this ambiguity. "The idea of the single, homogeneous, authentic people is a fantasy," writes Müller (2016a, loc. 57). Populists, however, behave as if there is an essential homogeneity, and the populist claim is based on the idea that only the populists can represent the people (Müller 2016a, loc. 49, loc. 1372). "They and they alone speak in the name of what they tend to call the 'real people' or the 'silent majority'” (Müller 2016c, p. 10, see also Müller 2017).

After the publication of his book, Müller (2017) warned against Trump's use of the term "the people" in the Inaugural Address. "January 20th, 2017, will be remembered as the day the people became the rulers of this nation again," (The White House 2017) declared Trump in his speech. Müller (2016c, p. 10) also refers to Nigel Farage, the leader of the UK Independence Party. In his speech, after the EU referendum, Farage had claimed the result of the referendum "as a victory for the real people", suggesting that 48 percent of the voters who voted against Brexit do not count as real people. According to Müller, this is the shared language of Trump, Farage, Orbán, Erdoğan, and the likes. Each and every populist employs the same mode of identification. The populist leader associates himself with the people, and thus claims that only his true self represents the people. A more striking example from the book comes from Turkey:

Think, for instance, of Turkish President Recep Tayyip Erdoğan declaring at a party congress in defiance of his numerous domestic critics, "We are the people. Who are you?" Of course, he knew that his opponents were Turks, too. The claim to exclusive representation is not an empirical one; it is always distinctly moral (Müller 2016a, loc. 49, see also Müller 2016b).

Populists, argues Müller, are necessarily anti-elitist. But being critical of elites does not suffice to be a populist. In accordance with Mudde (2004), Müller states that populists are always antipluralist as well. When in opposition, they see their political rivals as immoral elites. When 
in power, they do not recognize any legitimate opposition. They are the people, "righteous and morally pure." Anyone who does not support them is illegitimate, and does not belong to "the people." The implication is that they are the "100 percent." So, populism is an exclusionary form of identity politics that tends to threaten the very notion of democracy (Müller 2016a, loc. 50-60). It is not surprising that considerable segments of the society under populist regimes that do not identify with the populist leader feel threatened, and that their existence is denied - such as in the case of Alevis in Turkey (see Kingsley 2017).

Müller (2016a, loc. 70) points to three specific features of populist governance: (1) They attempt to hijack the state apparatus. Fifteen years of the AKP rule, especially the political trials, and the great purge that has taken place in Turkey after 2007 might have provided a very good example for the author. (2) Corruption and "mass clientalism." And finally, (3) They are always engaged in efforts to systematically suppress the civil society. Once again, ample proof, which has increased exponentially under the state of emergency that was declared by the AKP in July 2016, can be found in Turkey. Müller's book, of course, is not an empirical study - and thus does not go into the specifics of USA, UK, Turkey or Hungary.

What differentiates populists from any authoritarian regime in terms of the above-mentioned features is the populists' justification of their conduct. Since they claim that they alone represent the people, "they avow their practices quite openly." They claim to represent the common good as willed by the people (Müller 2016a, loc. 1381). Müller thinks this is also an explanation "why revelations of corruption rarely seem to hurt populist leaders" as in the case of Erdoğan's Turkey and Haider's Austria. Turan Subaşat's (2017) article in this issue of MGDR provides a detailed outline of the political economy of the populist regime in Turkey.

The most promising part of Müller's book might have been the final chapter (Müller 2016a, loc. 1043-1362) where the title suggests that he would discuss the ways to deal with populists. The chapter, however, is mainly dedicated to criticizing common responses to populism. Still, finally he proposes that to engage with populists, their political claims should be taken seriously without "taking them at face value" (Müller 2016a, loc. 1157). Populists should be criticized for being a real danger to democracy, asserts Müller. But "that does not necessarily mean that one should not engage them in political debate. One can take the problems they raise seriously without accepting the ways in which they frame these problems" (Müller 2016a, loc. 1390). 
For MGDR, with its emphasis on globalization and development, while the dominant approaches of its readers and contributors - focused as they are on markets and consumption - are economic and cultural, in the present era politics has moved to a central space in all popular and intellectual discussions. The book reviewed here provides sharp political insights into forces that are not only shaping markets in many individual major nations - USA, UK, Turkey, Russia and India, for example - but also reshaping global economic, political, and cultural connections among nations.

To respond to the question in the beginning of this review, yes, even without a theory of populism, Müller's book helps. It is timely and although steeped in political theory - it is accessible to a general readership. Originally published in German, it is a welcome contribution to the vast academic literature on populism. With almost simultaneous or immediate editions in English (2016), French (2016), Italian (2017), and a forthcoming edition in Turkish (2017), it could also be expected to prove to be a popular addition as well. 


\section{References}

Anderson, Perry (2017), "Why the system will win," Le Monde diplomatique, 1703, March, 6-7.

Arditi, Benjamin (2005), "Populism as an Internal Periphery of Democratic Politics," in Populism and the Mirror of Democracy, Francisco Panizza, ed. London: Verso, 72-98.

Arditi, Benjamin (2006), Politics on the Edges of Liberalism: Difference, Populism, Revolution, Agitation. Edinburgh: Edinburgh University Press.

Ionescu, Ghița, and Ernest Gellner, eds (1969), Populism: Its Meaning and National Characteristics. London: Weidenfeld and Nicolson.

Laclau, Ernesto (1977), "Towards a Theory of Populism," in Politics and Ideology in Marxist Theory: Capitalism, Fascism, Populism. London: New Left Books, 143-99.

Kingsley, Patrick (2017), "Turkey's Alevis, a Muslim Minority, Fear a Policy of Denying Their Existence," The New York Times, July 22, (accessed July 23, 2017), [available at https://goo.gl/TrtWj1].

Mény, Yves, and Yves Surel (2002), "The Constitutive Ambiguity of Populism," in Democracies and the Populist Challenge, Yves Mény and Yves Surel, eds. New York: Palgrave, 1-21.

Mudde, Cas (2004), "The Populist Zeitgeist," Government and Opposition, 39 (4), 541-63.

Mudde, Cas and Cristóbal Rovira Kaltwasser (2017), Populism: A Very Short Introduction. New York, NY: Oxford University Press, 2017.

Müller, Jan-Werner (2016a), What is Populism? Philadelphia, PA: University of Pennsylvania Press, Kindle edition.

Müller, Jan-Werner (2016b), "Trump, Erdoğan, Farage: The attractions of populism for politicians, the dangers for democracy," The Guardian, September 2, (accessed March 3, 2017), [available at https://goo.gl/inJv1U].

Müller, Jan-Werner (2016c), "The Populist Moment," London Review of Books, 38 (23), 10-14.

Müller, Jan-Werner (2017), "Donald Trump's use of the term 'the people' is a warning sign," The Guardian, January 24, (accessed March 3, 2017), [available at https://goo.gl/srd12r]. 
Panizza, Francisco (2005), "Introduction: Populism and the Mirror of Democracy," in Populism and the Mirror of Democracy, Francisco Panizza, ed. London: Verso, 1-31.

Subaşat, Turan (2017), "Turkey at a Crossroads: The Political Economy of Turkey's Transformation," Markets, Globalization \& Development Review, 2 (2), Article 6.

Taggart, Paul (2000), Populism. Buckingham PA: Open University Press.

Taggart, Paul (2002), "Populism and the Pathology of Representative Politics," in Democracies and the Populist Challenge, Yves Mény and Yves Surel, eds. New York: Palgrave, 62-80.

The White House (2017), "The Inaugural Address," January 20, (accessed March 3, 2017), [available at https://goo.gl/csFVwT]. 